Серебренникова А. Г., Асафьева Е. В., Ярош А. С.

A. G. Serebrennikova, E. V. Asafyeva, A. S. Yarosh

ЧЕМПИОНАТ WORLDSKILLS: ТЕОРЕТИЧЕСКИЕ ЗНАНИЯ, УМЕНИЯ, ПРАКТИЧЕСКИЕ НАВЫКИ

\title{
CHAMPIONSHIP WORLDSKILLS: THEORETICAL KNOWLEDGE AND SKILLS
}

Серебренникова Анжела Геннадьевна - кандидат технических наук, доцент кафедры «Технология машиностроения» ФГБОУ ВО «Комсомольский-на-Амуре государственный технический университет» (Россия, Комсомольск-на-Амуре). E-mail: S_angel@kmscom.ru.

Ms. Anzhela G. Serebrennikova - PhD in Engineering, Assistant Professor, Department of Mechanical Engineering Technology, Komsomolsk-on-Amur State Technical University (Russia, Komsomolsk-onAmur). E-mail: s_angel@kmscom.ru.

Асафьева Елизавета Вячеславовна - студентка группы 3КТб1 специальности «Конструкторскотехнологическое обеспечение машиностроительного производства» ФГБОУ ВО «Комсомольский-наАмуре государственный технический университет» (Россия, Комсомольск-на-Амуре).

E-mail: 1995-Liza@mail.ru.

Ms. Elizaveta V. Asafyeva - a student major in Design and technological support of machine-building production, Komsomolsk-on-Amur State Technical University (Russia, Komsomolsk-on-Amur).

E-mail: 1995-Liza@mail.ru.

Ярош Алёна Сергеевна - студентка группы 4КТб1 специальности «Конструкторско-технологическое обеспечение машиностроительного производства» ФГБОУ ВО «Комсомольский-на-Амуре государственный технический университет» (Россия, Комсомольск-на-Амуре).

E-mail: velosepedistka@mail.ru.

Ms. Alena S. Yarosh - a student major in Design and technological support of machine-building production, Komsomolsk-on-Amur State Technical University (Russia, Komsomolsk-on-Amur).

E-mail: velosepedistka@mail.ru.

Аннотация. В статье рассмотрены вопросы влияния участия студентов в конкурсах профессионального мастерства различного уровня на становление интереса к будущей выбранной специальности в стенах вуза.

Summary.The article discusses the participation of students in various competitions of professional skills and its role in getting interest in future specialty chosen within the University.

Ключевые слова: конкурс, чемпионат, профессия, навыки, знания, фрезерование.

Key words: competition, championship, profession, skills, knowledge, milling.

УДК 621.91 .01

На протяжении трех лет студенты ИКП МТО КнАГТУ специальности «Конструкторско-технологическое обеспечение машиностроительных производств» учувствуют в различного рода конкурсах и соревнованиях городского и регионального уровней.

Так, в декабре 2015 г. был проведён Городской конкурс профессионального мастерства среди студентов высших учебных заведений и RUSSia студентов учреждений профессионального образования по специальности «Фрезерные работы с ЧПУ», где студентка 2-го курса ФГБОУ ВО «КнАГТУ» А. С. Ярош заняла 3-е место.

Не так давно команда Комсомольского-на-Амуре государственного технического университета вернулась из г. Хабаровска, где Е. В. Асафьева заняла 2-е место в полуфинале WorldSkills Russia 2016 г. в компетенции «Фрезерные работы на станках с ЧПУ». Эта победа 


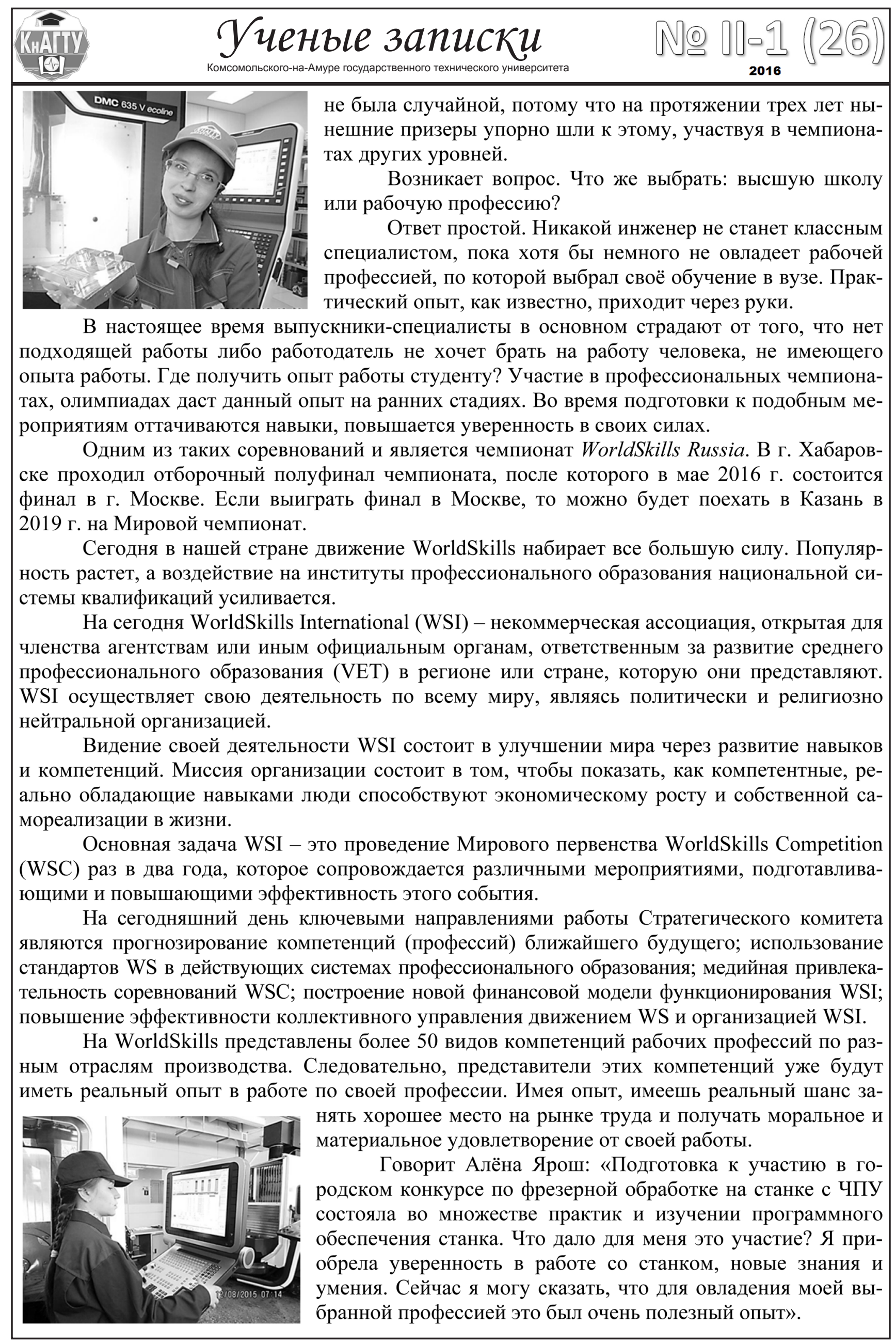

